\title{
PENDIDIKAN KARAKTER ANAK USIA DINI DALAM DIMENSI BERKETUHANAN
}

\author{
Harun $^{1}$, Amat Jaedun ${ }^{2}$, Sudaryanti ${ }^{1}$, dan Abdul Manaf ${ }^{3}$ \\ ${ }^{1}$ Fakultas Ilmu Pendidikan Universitas Negeri Yogyakarta \\ ${ }^{2}$ Fakultas Tehnik Universitas Negeri Yogyakarta \\ ${ }^{3}$ Pascasarjana Universitas Negeri Yogyakarta \\ email: harun@uny.ac.id
}

\begin{abstract}
Abstrak
Penelitian ini bertujuan untuk membuktikan dimensi pendidikan karakter anak usia dini terkait dengan hubungan ketuhanan. Metode penelitian yang digunakan adalah kuantitatif. Subjek penelitian sebanyak 451 anak yang berasal dari 26 lembaga PAUD di wilayah Daerah Istimewa Yogyakarta. Teknik pengumpulan datanya menggunakan kuesioner. Analisis data menggunakan confirmatory factor analysis second order. Kriteria yang digunakan untuk menyatakan model konstruk fit (kecocokan model) adalah absolute fit indices, incremental fit indicies, dan persimonius. Hasil penelitian ini juga menunjukan bahwa dimensi karakter anak usia dini yang berkaitan dengan hubungan ketuhanan terdiri atas: keyakinan/akidah, rajin beribadah, sikap ikhlas bertindak, dan nilai budi pekerti/ akhlakul karimah. Nilai sikap ikhlas bertindak merupakan faktor dominan sedangkan nilai budi pekerti/akhlakul karimah merupakan faktor yang kurang dominan pada pendidikan karakter anak usia dini di PAUD yang ada di Daerah Istimewa Yogyakarta. Semua indikator tersebut memberikan kontribusi terhadap sikap atau perilaku anak terkait dengan hubungan ketuhanan.
\end{abstract}

Kata kunci: pendidikan karakter, anak usia dini, hubungan ketuhanan

\section{DIMENSIONS OF EARLY CHILDHOOD EDUCATION CHARACTERS RELATED TO GOD'S RELATIONSHIP}

\begin{abstract}
This study aims to examine the dimensions of early childhood character education related to the divine relationship. This study method used was quantitative research. The research subjects were 451 kids from 26 preschool institutions in the Yogyakarta. The data were collected using questionnaire. The data analysis used second order confirmatory factor analysis. The criteria used to state the construct fit model were absolute fit indices, incremental fit indicies, and persimonius. The results show that the dimensions of early childhood character related to the divine relationship consist of: belief / faith, the obidience in worship, sincere action, and noble character. The value of sincere action is the dominant factor, while the noble character is a less dominant factor in early childhood character education in preschool in Yogyakarta. All of these indicators contribute to children's attitudes or behaviors related to divine relationships.

Keywords: educational character, early childhood, god's relationship
\end{abstract}




\section{PENDAHULUAN}

Di Indonesia karakter merupakan hal yang sangat penting, karena bangsa Indonesia sangat membutuhkan orangorang yang berkarakter baik untuk membangun bangsa. Karakter baik adalah ketika seseorang mampuh membiasakan berprilaku terpuji kapan dan dimana berada. Selain itu, kebiasaan tersebut dilakukan ketika dilihat maupun tidak dilihat orang lain. Karakter baik (good character) meliputi pengetahuan tentang kebaikan (cognitives), niat terhadap kebaikan (affectives), dan melakukan kebaikan (behaviors) (Lickona, 1991, p. 51).

Keseriusan pemerintah terkait pengembangan karakter terlihat sejak pendidikan karakter dicanangkan oleh presiden ke-6 Republik Indonesia yaitu Susiolo Bambang Yudhoyono dalam peringatan Hari Pendidikan Nasional, tepatnya pada tanggal 2 Mei 2010. Selanjutnya, Presiden Joko Widodo menginginkan untuk dilakukan penguatan pendidikan karakter di segala aspek kehidupan dengan diterbitkannya Peraturan Presiden Republik Indonesia Nomor 87 Tahun 2017 tentang Penguatan Pendidikan Karakter sehingga pendidikan karakter perlu ditanamkan sejak anak menempuh pendidikan di taman kanakkanak (TK) sampai perguruan tinggi.

Pendidikan karakter pada anak usia dini bertujuan untuk membentuk dan membangun pola pikir, sikap, dan perilaku para anak agar menjadi pribadi yang positif, berakhlak karimah, berjiwa luhur, dan bertanggung jawab dalam kehidupan sehari-hari. Azzet (2011, p. 68) menyatakan bahwa pendidikan karakter adalah suatu sistem yang meliputi komponen pengetahuan, kesadaran atau kemauan, dan tindakan untuk melaksanakan nilainilai tersebut. Pendidikan karakter anak usia dini diselenggarakan sebelum jenjang pendidikan dasar melalui pendidikan formal, nonformal, dan atau informal. Pada konteks pendidikan formal dapat berbentuk TK dan raudhatul athfal (RA), serta bentuk lainnya yang sederajat. Sementara pada jalur non formal dapat berbentuk kelompok bermain (KB) dan tempat penitipan anak (TPA), serta bentuk lainnya yang sederajat. Sedangkan jalur pendidikan informal berbentuk pendidikan keluarga atau pendidikan yang diselenggarakan oleh lingkungan (Helmawati, 2015, p. 6).

Pendidikan anak usia dini tidak hanya memenuhi hak azasi manusia mendapatkan pendidikan sedini mungkin melalui jalur formal, nonformal dan informal, melainkan juga sebagai peletakan dasar fondasi bagi pertumbuhan dan perkembangan segala potensi diri anak. Tujuan pendidikan anak usia dini adalah sebagai berikut. Pertama, anak mampu melakukan ibadah, mengenal dan percaya akan ciptaan Tuhan dan mencintai sesama manusia. Kedua, anak mampu berpikir logis, kritis, memberikan alasan, memecahkan masalah dan menemukan hubungan sebab akibat. Ketiga, anak mampu mengenal lingkungan alam, lingkungan sosial, peran masyarakat dan menghargai keragaman sosial dan budaya serta mampu mengembankan konsep diri, sikap positif terhadap belajar, kontrol diri, dan rasa memiliki (Sujiono \& Nurani, 2012, pp. 42-43). Pada dasarnya penyelenggaraan pendidikan karakter di sekolah dapat dilakukan secara terpadu pada setiap kegiatan sekolah. Setiap aktivitas peserta didik di sekolah dapat digunakan sebagai media untuk menanamkan karakter, mengembangkan konasi, dan memfasilitasi peserta didik berperilaku sesuai nilai-nilai yang berlaku (Rochayati \& Wardani, 2018).

Penanaman nilai karakter tersebut merupakan hal yang sangat sulit. Oleh karena itu, pada tingkat PAUD dipilih beberapa nilai karakter utama yang disarikan dari butir-butir SKL PAUD (Permendiknas 
Nomor 23 tahun 2010) dan SK/KD (Permendiknas Nomor 22 tahun 2010). Berikut adalah aspek karakter utama yang dimaksud dan didiskripsikan secara ringkas. Pertama, nilai karakter dalam hubungannya dengan ketuhanan: pikiran, perkataan, dan tindakan seseorang yang diupayakan selalu berdasarkan pada nilai-nilai ketuhanan dan atau ajaran agamanya. Kedua, nilai karakter dalam hubungannya dengan diri sendiri: jujur, toleransi, disiplin, kerja keras, kreatif, mandiri, demokratis, rasa ingin tahu, semangat kebangsaan, cinta tanah air, menghargai prestasi, bersahabat, cinta damai, gemar membaca, peduli lingkungan, peduli sosial, tanggung jawab. Ketiga, nilai karakter dalam hubungannya dengan sesama: sadar akan hak dan kewajiban diri dan orang lain; patuh pada aturan-aturan hukum dan adat; menghargai karya dan prestasi orang lain; perilaku santun sesama orang. Keempat, nilai karakter hubungannya dengan lingkungan: sikap dan tindakan yang selalu berupaya mencegah kerusakan pada lingkungan alam di sekitarnya, selalu ingin memberi bantuan bagi orang lain dan masyarakat yang membutukan. Kelima, nilai kebangsaan; cara pikir, wawasan yang menempatkan kepentingan bangsa dan negara di atas kepentingan diri dan kelompoknya; nasionalis; menghargai keberagaman (Kemendiknas, 2010, pp. 16-19).

Persoalan yang tidak kalah penting dalam pendidikan karakter anak usia dini adalah karakter terkait dengan hubungan Tuhan yang mahakuasa (ketuhanan). Dalam kontes ini, Azzet (2011, pp. 8889) menyatakan bahwa, anak harus dikembangkan karakternya agar benarbenar berkeyakinan, bersikap, berkata-kata dan berprilaku sesuai dengan ajaran agama yang dianutnya. Kepercayaan yang dimiliki akan mengantarkan anak memiliki karakter yang baik, sehingga terbentuk konsep diri yang baik. Cinta Tuhan dan segenap ciptaannya adalah merupakan bagian dari pilar karakter (Wulandari, Wijayanti, \& Saliman, 2019).

Pendidikan karakter anak usia dini di lembaga formal, nonformal, dan atau informal salah satu tujuannya yaitu mendidik anak untuk selalu tertib dan disiplin dalam beribadah secara terus menerus. Membiasakan anak untuk beribadah maka didalam dirinya akan tertanam sistem keyakinan yang kuat. Dalam konteks ini, Majid dan Andayani (2013, p. 101) menyatakan bahwa, keyakinan (aqidah) yang kuat dan bersih pada diri seseorang, akan memiliki ikatan yang kuat dengan Tuhan yang maha kuasa, sehingga segala perbuatan atau tindakannya tidak akan menyimpang dari jalan dan ketentuan yang telah ditetapkan. Selain itu, seseorang akan menyerahkan segala perbuatannya hanya kepada Tuhan sebagai pencipta alam semesta.

Dalam perkembangan kepercayaan pada anak usia dini, Desmita (2014, p. 279) membaginya menjadi tiga tahap yaitu: tahap prima faith (usia 0-2 tahun) ditandai dengan rasa percaya dan setia anak pada pengasuhnya; tahap intuitiveprojective faith (usia 2-7 tahun). Pada tahap ini kepercayaan anak bersifat peniruan, karena kepercayaan yang dimilikinya masih merupakan gabungan hasil pengajaran dan contoh-contoh signifikan dari orang dewasa; dan tahap mythic-literal faith (usia 7-11 tahun). Pada tahap ini, anak secara sistematis mulai mengambil makna dari tradisi masyarakatnya. Gambaran tentang Tuhan diibaratkan sebagai seorang pribadi, orang tua atau penguasa yang bertindak dengan sikap tegas.

Sjarkawi (2015, p. 32) menyatakan bahwa akhlak mengajarkan bagaimana seseorang seharusnya berhubungan dengan Tuhan penciptanya, sekaligus bagaimana 
seseorang seharusnya berhubungan dengan sesama manusia. Lebih lanjut Sjarkawi (2015) menegaskan orang yang berakhlak akan menjujung tinggi nilai-nilai antara lain kasih sayang, kebenaran, kebaikan, kejujuran, keindahan, amanah, tidak menyakiti orang lain, dan sejenisnya. Rohmadi dan Taufik (2010) menyatakan secara etimologi, kata akhlak yang berarti tabiat; budi pekerti, kebiasaan atau adat; keperwiraan, kesatriaan, kejantanan, agama; dan kemarahan. Hal ini menunjukkan bahwa untuk menjadi pribadi berakhlak dapat ditunjukkan dengan mematuhi nilai-nilai kebiasaan atau adat yang telah ditetapkan. Nilai keyakinan/akidah, rajin beribadah, sikap ikhlas bertindak, dan budi pekerti/ akhlakul karimah merupakan pilar karakter anak usia dini terkait dengan hubungan ketuhanan sehingga menjadi fokus dalam penelitian ini.

\section{METODE}

Penelitian ini menggunakan pendekatan kuantitatif. Rancangan penelitian ini menguji dimensi karakter anak usia dini yang terkait dengan hubungan Ketuhanan. Lokasi penelitian di wilayah Daerah Istimewa Yogyakarta. Subjek penelitian ditunjukan pada Tabel 1.

Tabel 1

Subjek Penelitian

\begin{tabular}{lcc}
\hline Kota/Kabupaten & $\begin{array}{r}\text { Sekolah } \\
\text { PAUD }\end{array}$ & Subjek \\
\hline Bantul & 6 PAUD & 118 \\
Kulon Progo & 1 PAUD & 18 \\
Gunung Kidul & 7 PAUD & 117 \\
Sleman & 5 PAUD & 86 \\
Kota Yogyakarta & 7 PAUD & 112 \\
\hline \multicolumn{1}{c}{ Total } & 26 PAUD & 451 \\
\hline
\end{tabular}

Dimensi karakter anak usia dini yang berkaitan dengan hubungan ketuhanan terdiri atas 4 indikator meliputi keyakinan/ akidah (KA), rajin beribadah (RB), sikap ikhlas bertindak (SK), dan nilai budi pekerti/akhlakul karimah (BP). Instrumen pengumpulan data menggunakan lembar kuesioner yang diisi oleh guru. Instrumen tersebut digunakan untuk mengumpulkan data dimensi karakter anak usia dini berkaitan dengan hubungan ketuhanan. Instrumen tersebut memuat 12 butir pernyataan yang mengukur 4 indikator yaitu: KA terdiri atas 3 butir, RB terdiri atas 3 butir, SK terdiri atas 3 butir, dan BP terdiri atas 3 butir. Secara rincinya dintunjukkan pada Tabel 2.

Data kuantitatif yang diperoleh dianalisis dengan confirmatory factor analysis (CFA) dengan pendekatan second order. Penggunakan program LISREL 8.50, untuk memudahkan dalam proses analisinya. Kriteria yang digunakan untuk menyatakan model konstruk fit (kecocokan model) adalah absolute fit indices, incremental fit indicies, dan persimonius (SchermellehEngel, Moosbrugger, \& Mueler, 2003; Hair, Anderson, Tatham, \& Black 2010, pp. 578-581).

\section{HASIL PENELITIAN DAN PEMBAHASAN}

Data penelitian yang diperoleh dianalisis dengan confirmatory factor analysis second order. Proses analisis dilakukan sebanyak tiga kali yaitu analisis awal, reanalisis 1, dan reanalisis 2. Proses reanalisis 1 dilakukan karena pada analisis awal ditemukan ada butir pernyataan yang tidak memenuhi kriteria loading faktor (lebih besar atau sama dengan 0,5) dan konstruknya tidak memenuhi fit model. Begitu pula hasil reanalisis 1, masih ditemukan butir pernyataan yang tidak memenuhi kriteria loading faktor sehingga dilakukan reanalisis 2. Berdasarkan analisis awal diperoleh hasil seperti yang disajikan pada Tabel 3. 
Tabel 2

Kisi-kisi Instrumen

\begin{tabular}{llc}
\hline \multicolumn{1}{c}{ Indikator } & \multicolumn{1}{c}{ Pernyataan } & $\begin{array}{c}\text { No } \\
\text { Butir }\end{array}$ \\
\hline Keyakinan/ & Percaya kepada kekuasaan Tuhan & 1 \\
akidah & Percaya kepada nasib keadaan seseorang & 2 \\
& Percaya kepada adanya pertolongan orang lain & 3 \\
Rajin beribadah & Setiap hari anak berdoa kepada Tuhan & 4 \\
& Setiap hari anak beribadah sebagai perintah Tuhan & 5 \\
\multirow{2}{*}{ Sikap ikhlas } & Setiap hari anak beribadah tepat waktu & 6 \\
bertindak & Anak menolong teman lain tanpa pamrih & 7 \\
\multirow{4}{*}{$\begin{array}{l}\text { Nilai budi } \\
\text { pekerti/akhlakul } \\
\text { karimah }\end{array}$} & Anak tidak meminta imbalan ketika menolong orang lain & 8 \\
& Anak menolong orang/teman lain tanpa pilih kasih & 9 \\
& Anak berbicara dengan tutur kata yang baik & 10 \\
\hline
\end{tabular}

Tabel 3

Hasil Analisis CFA Second Order

\begin{tabular}{|c|c|c|c|}
\hline $\begin{array}{c}\text { Goodness } \\
\text { of Fit }\end{array}$ & $\begin{array}{l}\text { Cut of } \\
\text { Value }\end{array}$ & Value & Decision \\
\hline NFI & $\geq 0,90$ & 0,74 & $\begin{array}{l}\text { Tidak } \\
\text { Baik }\end{array}$ \\
\hline CFI & $\geq 0,90$ & 0,76 & $\begin{array}{l}\text { Tidak } \\
\text { Baik }\end{array}$ \\
\hline IFI & $\geq 0,90$ & 0,76 & $\begin{array}{l}\text { Tidak } \\
\text { Baik }\end{array}$ \\
\hline RFI & $\geq 0,90$ & 0,66 & $\begin{array}{l}\text { Tidak } \\
\text { Baik }\end{array}$ \\
\hline AGFI & $\geq 0,90$ & 0,69 & $\begin{array}{l}\text { Tidak } \\
\text { Baik }\end{array}$ \\
\hline
\end{tabular}

Tabel 3 menunjukkan bahwa keseluruhan persyaratan goodness of fit pada jenis incremental fit tidak terpenuhi, begitu pula pada jenis absolute fit indices, dan persimonius tidak terpenuhi, karena nilai yang diperoleh tidak berada dalam interval yang ditentukan, sehingga dikatakan bahwa model yang diperoleh adalah tidak fit. Karena model tidak fit maka dilakukan reanalisis 1 .
Pada dimensi karakter anak usia dini terkait dengan hubungan ketuhanan memiliki 12 butir pernyataan. Berdasarkan output standardized factor loading, diperoleh butir KA2 $(0,85)$; KA3 $(0,86)$; RB1 (0,53); RB2 (0,80), RB3 (0,73); SK1 $(0,71)$; SK2 (0,80); SK3 $(0,87)$; BP1 $(0,83)$; dan BP3 $(0,73)>0,5$; sedangkan KA1 $(0,37)$ dan BP2 $(0,46)<0,5$. Hal ini, ditunjukkan dari diagram CFA second order berdasarkan standar solution pada Gambar 1 dan berdasarkan $t_{\text {value }}$ pada Gambar 2 .

Berdasarkan nilai loading faktor dan nilai $t$-value, tampak bahwa hanya ada dua butir pernyataan yaitu KA1 dan BP2 yang tidak memenuhi kriteria. Hal ini, dapat dilihat dari $t_{-}{ }_{\text {value }}$ lebih kecil dari nilai $t_{-}{ }_{\text {tabel }}$ 1,96 , sehingga diperoleh 10 butir yang memberikan kontribusi terhadap masingmasing indikator karakter anak usia dini terkait dengan hubungan ketuhanan.

Berdasarkan Gambar 1 dan Gambar 2, nilai loading faktor dari indikator KA $(0,53)$; RB $(0,53)$; SK $(0,77)$; dan BP $(0,78)$ $>0,5$ dan nilai $t_{\text {value }_{-}}$nya $>1,96$. Artinya, setiap indikator memberikan kontribusi 
Gambar 1. CFA Second Order Diagram Based on Standardized Solution

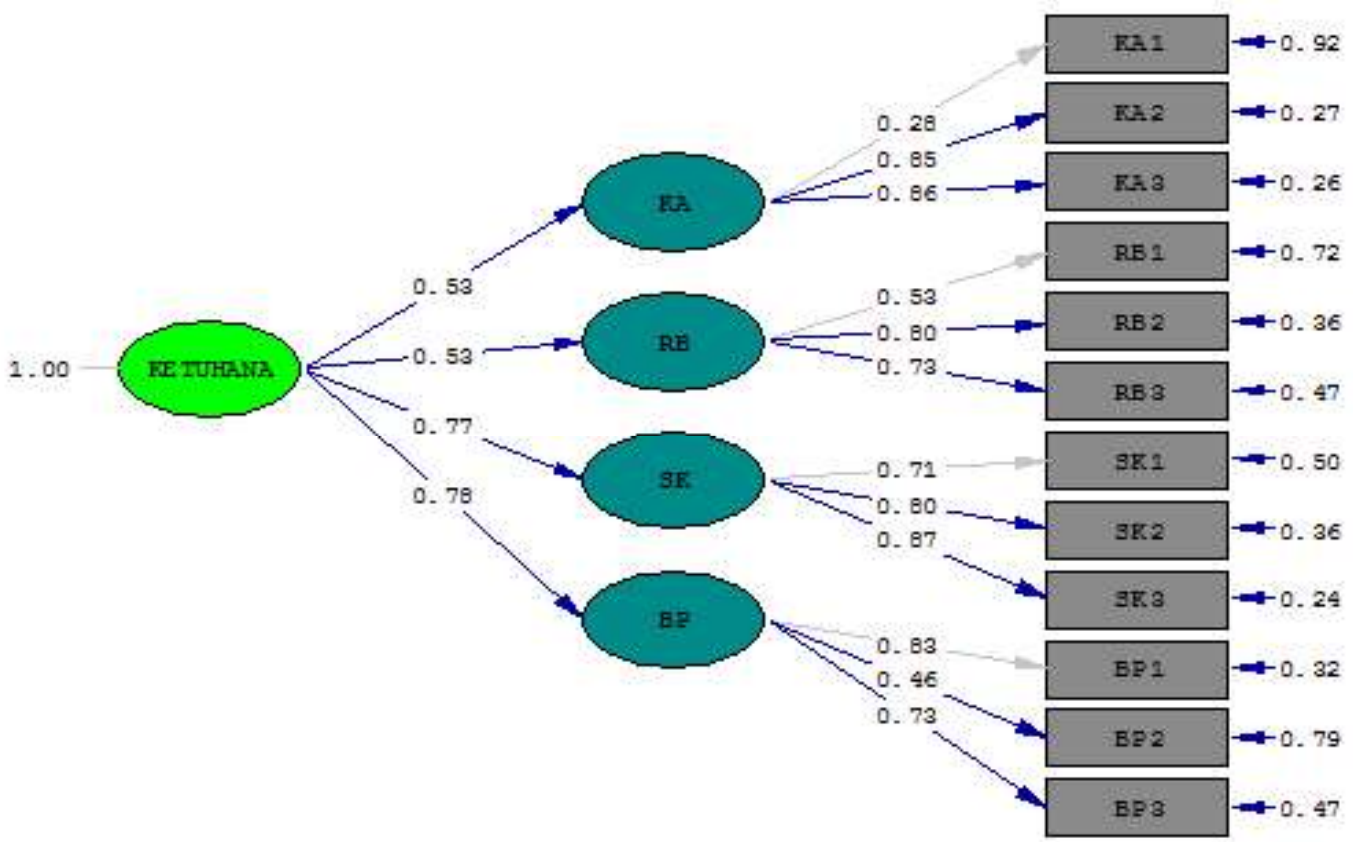

Chi-Square $=663.93, d f=50, P-$ value $=0.00000$, RMSEA $=0.165$

Gambar 2. CFA Second Order Diagram Based on $T_{\text {value }}$

0.00
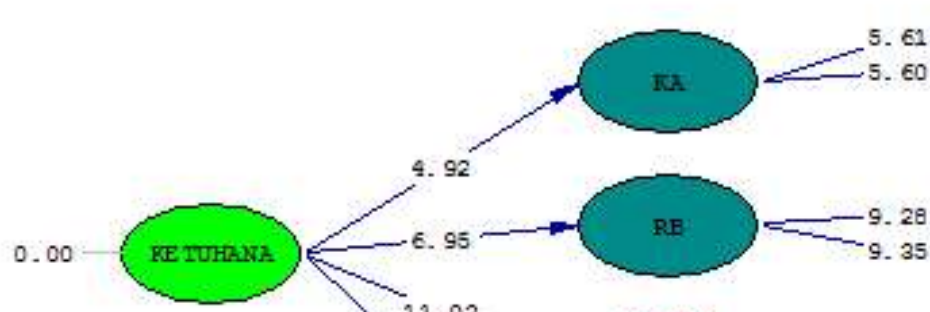

61
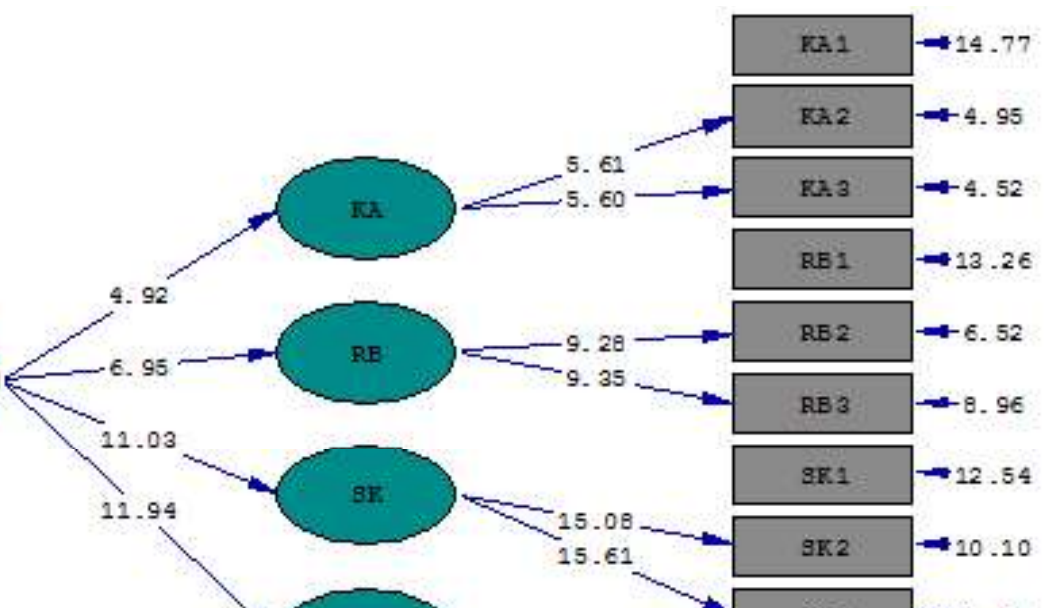

BP
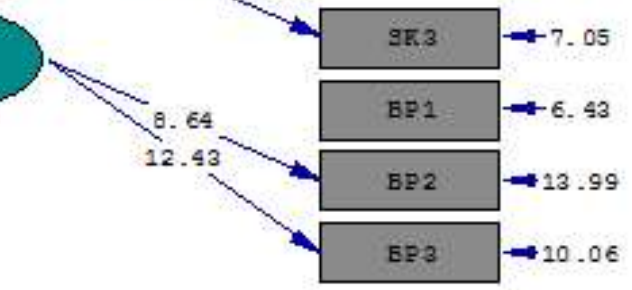

Chi-Square $=663.93, \mathrm{df}=50, \mathrm{P}-\mathrm{value}=0.00000, \mathrm{RMSEA}=0.165$ 
terhadap dimensi pendidikan karakter anak terkait dengan hubungan ketuhanan.

Reanalisis 1 dilakukan terhadap 10 butir pernyataan yang memenuhi kriteria nilai loading faktor. Berdasarkan reanalisis diperoleh hasil seperti yang disajikan pada Tabel 4.

Tabel 4

Hasil Analisis CFA Second Order

\begin{tabular}{lccc}
\hline $\begin{array}{c}\text { Goodness } \\
\text { of Fit }\end{array}$ & $\begin{array}{c}\text { Cut of } \\
\text { Value }\end{array}$ & Value & Decision \\
\hline NFI & $\geq 0,90$ & 0,97 & Baik \\
CFI & $\geq 0,90$ & 0,98 & Baik \\
IFI & $\geq 0,90$ & 0,98 & Baik \\
RFI & $\geq 0,90$ & 0,93 & Baik \\
AGFI & $\geq 0,90$ & 0,92 & Baik \\
\hline
\end{tabular}

Tabel 4 menunjukkan bahwa keseluruhan persyaratan goodness of fit pada jenis incremental fit telah terpenuhi karena nilai yang diperoleh berada dalam interval yang diperlukan sehingga dikatakan bahwa model yang diperoleh adalah fit. Karena model fit, maka dimensi pendidikan karakter anak usia dini terkait dengan hubungan ketuhanan di keresidenan Yogyakarta terdiri atas: keyakinan/akidah (KA), rajin beribadah (RB), sikap ikhlas bertindak (SK), dan nilai budi pekerti/ akhlakul karimah (BP).

Dimensi karakter anak terkait dengan hubungan ketuhanan memiliki 10 butir pernyataan. Berdasarkan output standardized factor loading, diperoleh butir KA2 $(0,85), \operatorname{KA} 3(0,87)$, RB2 $(0,64)$, RB3 $(0,91)$, SK1 $(0,89)$, SK2 $(0,58)$, SK3 $(0,64)$, BP1 $(0,71)$, dan BP2 $(0,81)>0.5$, sedangkan RB1 $(0,39)<0,5$. Hal ini, dapat ditunjukkan dari diagram CFA second order berdasarkan standard solution pada Gambar 3 dan nilai t-value pada Gambar 4.

Gambar 3. CFA Second Order Diagram Based on Standardized Solution

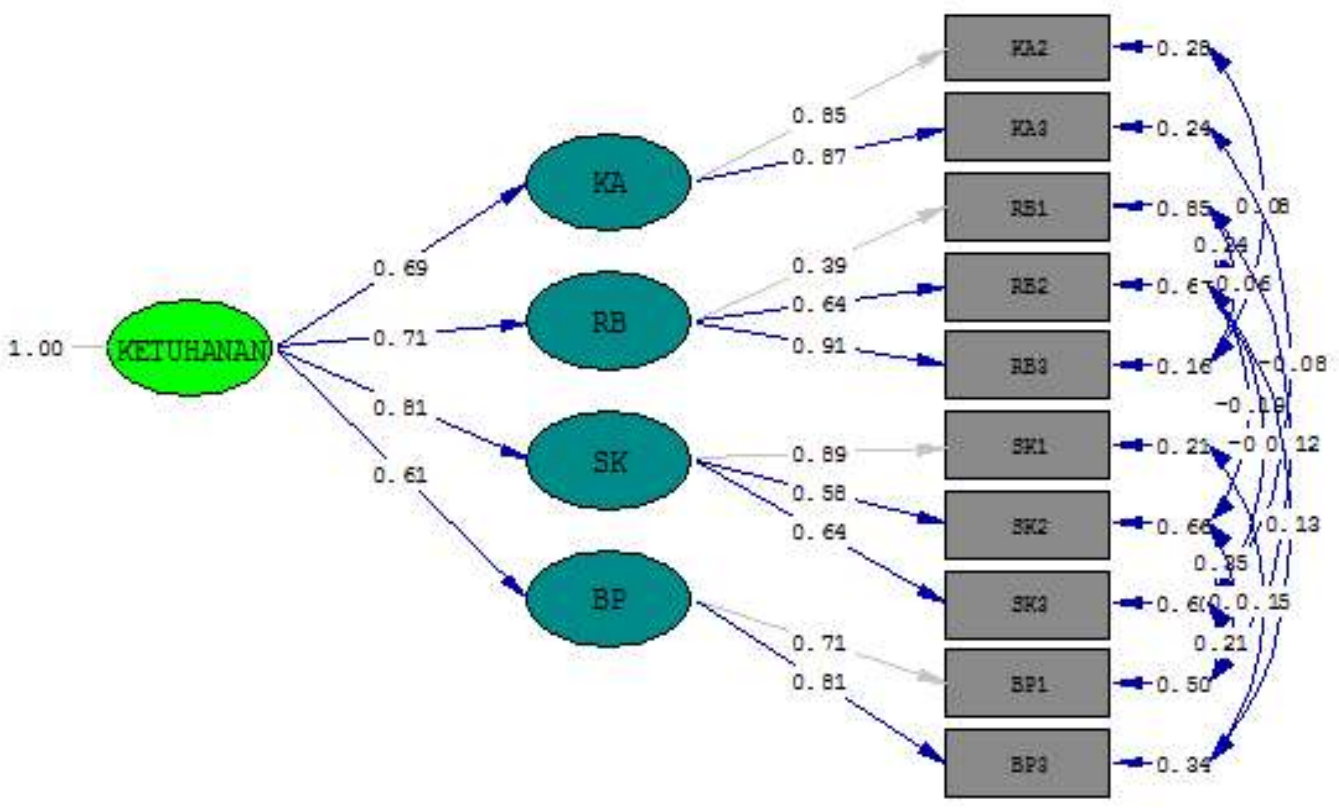

Chi-Square $=60.04, d f=19, \mathrm{P}-\mathrm{value}=0.00000, \mathrm{RMSEA}=0.069$ 
Gambar 4. CFA Second Order Diagram Based on T-value

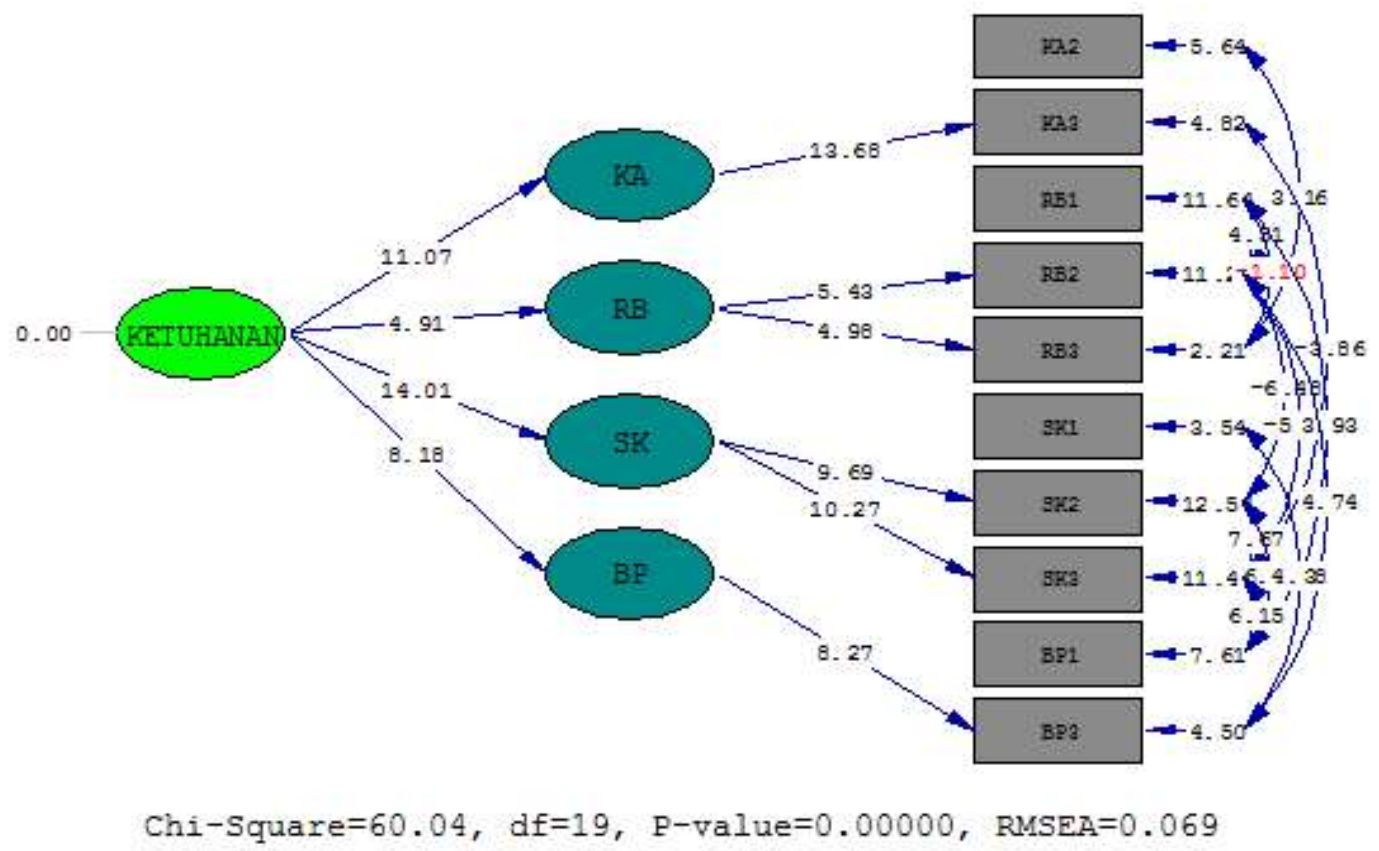

Nilai loading faktor dan $t_{\text {value, }}$, menunjukkan bahwa hanya ada satu butir pernyataan yaitu RB1 yang merupakan butir dari indikator RB tidak memenuhi kriteria. Hal ini, dapat dilihat dari $t^{-}{ }_{\text {value }}$ lebih kecil dari nilai $t_{\text {tabel }} 1,96$ sehingga diperoleh 9 butir pernyataan yang memberikan kontribusi terhadap masing-masing indikator karakter anak usia dini terkait dengan hubungan Ketuhanan.

Pada Gambar 3 dan 4, nilai loading faktor dari indikator $\mathrm{KA}(0,69)$; RB $(0,71)$; SK $(0,81)$; dan BP $(0,61)>0,5$ dan nilai $t_{\text {value }}$-nya $>1,96$. Artinya, setiap indikator memberikan kontribusi terhadap dimensi pendidikan karakter anak usia dini terkait dengan hubungan ketuhanan.

Reanalisis 2 dilakukan karena masih terdapat butir yang belum memenuhi kriteria loading faktor meskipun konstruknya sudah memenuhi model fit. Berdasarkan reanalisis 2 diperoleh hasil seperti yang disajikan pada Tabel 5.
Tabel 5

Hasil Analisis CFA Second Order

\begin{tabular}{llll}
\hline $\begin{array}{c}\text { Goodness } \\
\text { of Fit }\end{array}$ & $\begin{array}{l}\text { Cut of } \\
\text { Value }\end{array}$ & Value & Decision \\
\hline NFI & $\geq 0,90$ & 0,97 & Baik \\
CFI & $\geq 0,90$ & 0,98 & Baik \\
IFI & $\geq 0,90$ & 0,98 & Baik \\
RFI & $\geq 0,90$ & 0,93 & Baik \\
AGFI & $\geq 0,90$ & 0,92 & Baik \\
\hline
\end{tabular}

Tabel 5 menunjukkan bahwa keseluruhan persyaratan goodness of fit pada jenis incremental fit telah terpenuhi karena nilai yang diperoleh berada dalam interval yang diperlukan, sehingga dikatakan bahwa model yang diperoleh adalah fit. Karena model fit maka dimensi pendidikan karakter anak usia dini berkaitan dengan hubungan ketuhanan di keresidenan Yogyakarta terdiri atas: keyakinan/akidah (KA), rajin beribadah (RB) butir, sikap ikhlas bertindak (SK), dan nilai budi pekerti/akhlakul karimah (BP). 
Dimensi hubungan anak berkaitan dengan hubungan ketuhanan memiliki 9 butir pernyataan. Berdasarkan output standardized factor loading, diperoleh butir KA2 $(0,88)$; KA3 $(0,84)$; RB2 $(0,58) ; \mathrm{RB} 3$ $(1,00)$; SK $1(0,94)$; SK2 $(0,55)$; SK3 $(0,61)$; BP1 $(0,69)$; dan BP2 $(0,83)>0,5$. Hal ini dapat ditunjukkan dari diagram CFA second order berdasarkan standar solution pada Gambar 5 dan $t_{\text {- }}$ alue pada Gambar 6.

Loading faktor dan $t_{-}{ }_{\text {value }}$ menunjukkan bahwa tidak ada butir yang tidak memenuhi kriteria yang ditentukan. Hal ini dapat dilihat dari $t_{\text {value }}$ lebih besar dari nilai $t^{{ }_{\text {tabel }}}$ 1,96 sehingga diperoleh 9 butir yang memberikan kontribusi terhadap masingmasing indikator karakter anak usia dini terkait dengan hubungan ketuhanan.

Gambar 5 dan 6 menunjukkan nilai loading faktor dari indikator KA $(0,71)$; $\mathrm{RB}(0,68)$; SK $(0,75)$; dan BP $(0,57)>0,5$ dan nilai $t_{\text {value }}$-nya $>1,96$. Artinya. setiap indikator memberikan kontribusi terhadap dimensi pendidikan karakter anak usia dini berkaitan dengan hubungan ketuhanan.

Pendidikan karakter anak usia dini yang dilaksanakan daerah penelitian sudah menanamkan nilai-nilai karakter yang berkaitan dengan hubungan ketuhanan. Nilai karakter yang ditanamkan yaitu keyakinan/ akidah, rajin beribadah, sikap ikhlas bertindak, dan nilai budi pekerti/akhlakul karimah.

Sikap ikhlas bertindak adalah nilai karakter yang sangat menonjol pada anak usia dini yang berkaitan dengan hubungan ketuhanan. Hal ini ditandai dengan nilai loading faktor yang lebih besar. Sikap ikhlas bertindak ditunjukkan dengan sikap atau perilaku anak menolong teman lain tanpa pamrih, anak tidak meminta imbalan ketika menolong lain, dan anak menolong orang/teman lain tanpa pilih kasih.

Keyakinan/akidah yang ditunjukan anak usia dini, sudah cukup baik meliputi percaya kepada kekuasaan Tuhan, percaya

Gambar 5. CFA Second Order Diagram Based on Standardized Solution

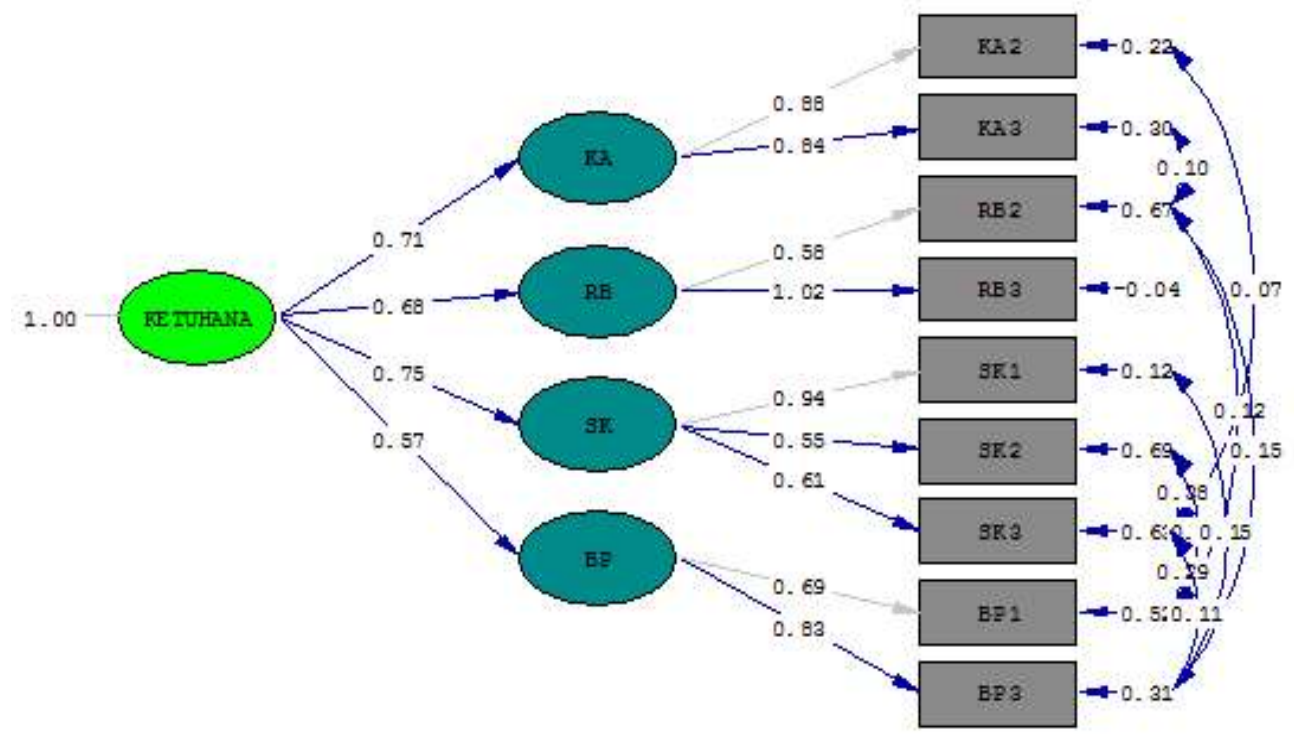

Chi-Square $=50.12, \mathrm{df}=14, \mathrm{P}-\mathrm{value}=0.00001, \mathrm{RMSEA}=0.076$ 
Gambar 6. CFA Second Order Diagram Based on $T_{\text {-value }}$

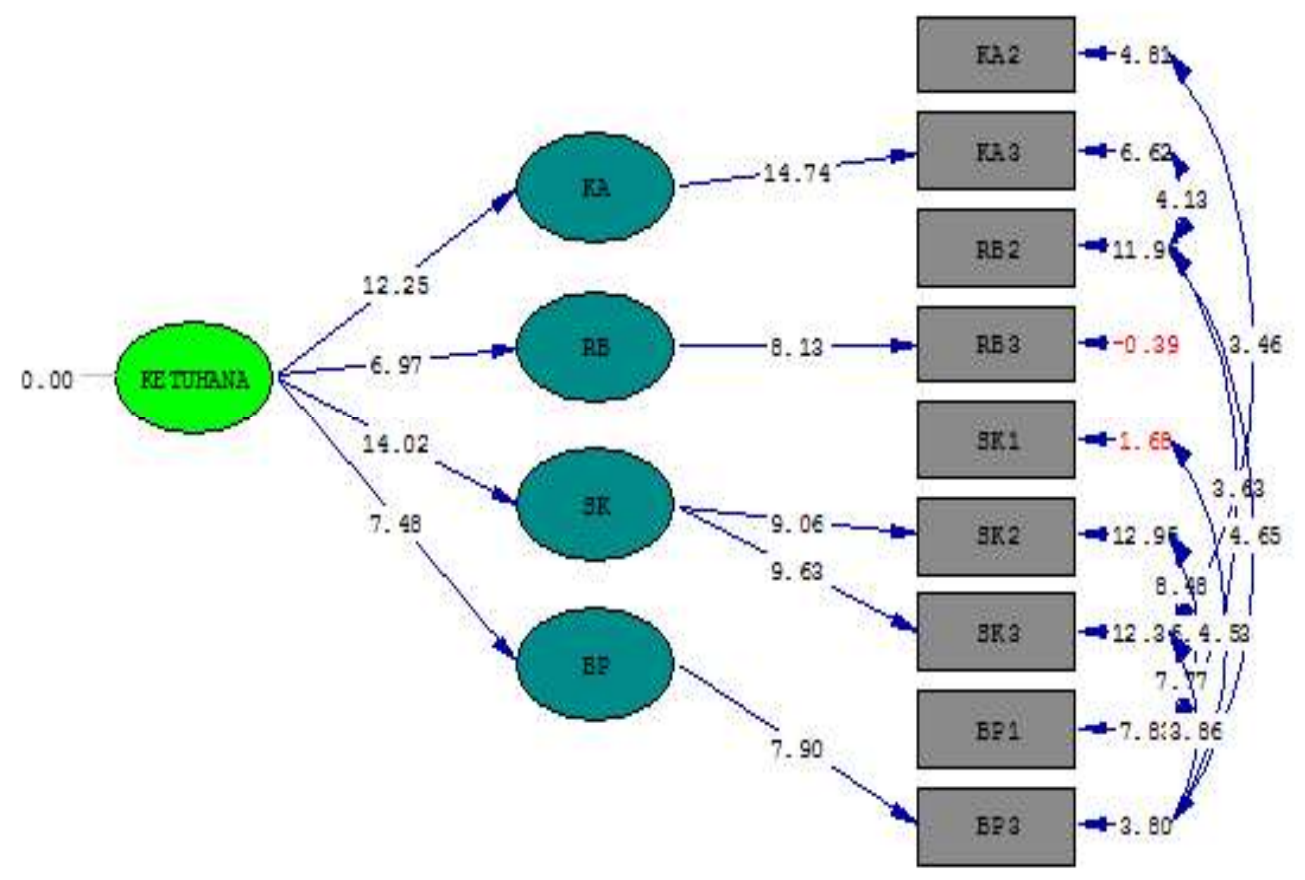

Chi-Square $=50.12, d f=14, P$-value $=0.00001$, RMSEA $=0.076$

kepada nasib keadaan seseorang, dan percaya kepada adanya pertolongan orang lain. Hasil penelitian ini selaras dengan pendapat Desmita (2014, p. 279) yang menyatakan bahwa kepercayaan anak bersifat peniruan, karena kepercayaan yang dimilikinya masih merupakan gabungan hasil pengajaran dan contoh-contoh signifikan dari orang dewasa; dan gambaran tentang Tuhan diibaratkan sebagai seorang pribadi, orang tua atau penguasa yang bertindak dengan sikap tegas. Perilaku rajin beribadah yang ditunjukan juga sudah cukup baik meliputi setiap hari anak berdoa kepada Tuhan, setiap hari anak beribadah sebagai perintah Tuhan, dan setiap hari anak beribadah tepat waktu.

Budi pekerti/akhlakul karimah adalah nilai karakter yang belum menonjol pada anak usia dini yang berkaitan dengan hubungan ketuhanan. Hal ini ditandai dengan nilai loading faktor yang lebih kecil. Budi pekerti/akhlakul karimah ditunjukkan dengan sikap atau perilaku anak berbicara dengan tutur katan yang baik, dan anak bersikap sopan dan santun kepada orang lain.

Bertalian dengan karakter yang dimiliki seorang anak dalam pandangan Islam, Sopiatin dan Sahrani (2011, pp. 99101) menyatakan bahwa fase kehidupan di dunia dalam perspektif islam adalah sebagai berikut. Pertama, bayi (at-thif). Usia bayi berkisar sejak lahir sampai dua minggu tidak memiliki kemampuan apapun yang ada hanya hidayah insting. Kedua, islam. Anak-anak yang belum cukup usia (shaby). Usia dua minggu sampai tujuh tahun sudah punya perasaan ketuhanan, perilakunya dipengaruhi oleh yang dilihat, 
didengar, dan stimulus campuran. Ketiga, aqil (mumayyiz). Anak yang telah berakal usia tujuh tahun sampai sembilan tahun mampu membedakan baik dan buruk menurut pandangan logika. Keempat, awal adolense (murahiq). Remaja awal usia sembilan tahun sampai sebelas tahun mulai mencari teladan untuk dijadikan idola. Hal ini menunjukkan bahwa ada empat fase yang dilalui seorang anak. Pada fase aqil anak sudah mulai dapat membedakan baik dan buruk.

Dalam konsep pendidikan karakter menurut ajaran agama islam bahwa budi pekerti/akhlakul karimah merupakan nilai karakter yang sangat ditekankan kepada setiap anak. Sebagaimana terdapat dalam Al-Hadis yang berbunyi "Sesungguhnya Allah itu adalah Zat Yang Mahamulia, karena itu dicintai-Nya kemuliaan, juga budi pekerti luhur dan benci pada akhlak yang hina (HR Abu Na'im dari Sahal ibn Sa'ad)".

Berdasarkan hal tersebut, pendidikan karakter anak usia dini berkaitan dengan penanaman nilai budi pekerti/akhlakul karimah perlu ditingkatkan baik pada lembaga formal, nonformal, dan atau informal. Pelaksanaan pendidikan karakter harus dengan penuh kehati-hatian. Karena anak usia dini adalah anak yang ada dalam tahap perkembangan pra-operasional konkrit, sementara nilai-nilai karakter merupakan konsep yang masih abstrak, sehingga dibutuhkan metode yang tepat dan efektif dalam menanamkan nilai-nilai karakter kepada anak (Wibowo, 2013, p. 51).

Pendidikan karakter dapat dilakukan melalui tiga desain sgar dapat berjalan efektif. Pertama, desain berbasis kelas, yang berbasis pada relasi guru sebagai pendidik dan anak sebagai pembelajar. Kedua, desain berbasis kultur sekolah, yang berusaha membangun kultur sekolah yang mampuh membentuk karakter anak dengan bantuan pranata sosial sekolah agar nilai tertentu terbentuk dalam diri anak. Ketiga, desain berbasis komunitas (Asmani, 2011, p. 155).

Supartinah, Kawuryan, dan Hastuti, (2018) menyatakan bahwa anak membutuhkan cara khusus dalam memahami pendidikan karakter sesuai dengan usia perkembangannya. Oleh karena itu, internalisasi pendidikan karakter di setiap mata pelajaran di sekolah PAUD menjadi hal yang penting. Untuk menanamkan karakter positif pada anak, pendidikan karakter harus dilakukan secara terus menerus hingga menjadi kebiasaan yang terus dipraktikkan dan dilakukan (Solihati, Hikmat, Jupri, \& Hidayatullah, 2019).

Demensi pendidikan karakter anak yang berkaitan dengan hubungan ketuhanan merupakan hal yang sangat penting, karena ini merupakan dasar dalam berprilaku mulia atau berbuat baik. (Azzet, 2011, p. 68) menyatakan bahwa tanda yang paling penting bagi seorang anak dalam beragama dengan baik adalah apabila mampuh mengamalkan ajaran agama yang dianutnya dalam kehidupan sehari-hari.

Pembinaan atau penanaman nilainilai karakter anak usia dini terkait dengan hubungan ketuhanan dilakukan sejak dini maka akan memberikan dasar-dasar pembentukan karakternya. Apabila anak telah terbiasa berbuat baik maka akan tertanam rasa itu kedalam jiwanya dan menjadi kontrol pribadi terhadap sikap dan perbutannya.

\section{SIMPULAN}

Berdasarkan hasil analisis data, dan pembahasan dapat ditarik kesimpulan sebagai berikut. Pertama, dimensi pendidikan karakter anak usia dini terkait dengan hubungan ketuhanan di sekolah PAUD yang ada di Daerah Istimewa 
Yogyakarta terdiri atas: keyakinan/akidah, rajin beribadah, sikap ikhlas bertindak, dan nilai budi pekerti/akhlakul karimah. Nilai-nilai karakter tersebut dapat dijadikan sebagai kekuatan karakter anak dalam kehidupan sehari-hari. Kedua, nilai sikap ikhlas bertindak merupakan faktor (indikator) dominan pada pendidikan karakter anak usia dini di PAUD yang ada di Daerah istimewa Yogyakarta. Ketiga, nilai budi pekerti/akhlakul karimah merupakan faktor (indikator) kurang dominan pada pendidikan karakter anak usia dini di PAUD yang ada di Daerah Istimewa Yogyakarta.

\section{DAFTAR PUSTAKA}

Asmani, J. M. (2011). Buku panduan internalisasi pendidikan karakter di sekolah. Yogyakarta DIVA Press:.

Azzet, A. M. (2011). Urgensi pendidikan karakter di Indonesia. Yogyakarta: Ar-Ruzz Media.

Desmita. (2014). Psikologi perkembangan peserta didik: Panduan bagi orang tua dan guru dalam memahami psikologi anak usia SD, SMP, dan $S M A$. Bandung: Remaja Rosdakarya.

Hair, J. F., Anderson, R. E., Tatham, R. L., \& Black, W. C. (2010). Multivariate data analysis ( $4^{\text {th }}$ ed.). New Jersey: Prentice Hall.

Helmawati. (2015). Mengenal dan memahami PAUD. Bandung: PT Remaja Rosdakarya.

Kemendiknas. (2010). Panduan pendidikan karakter di sekolahmenengah pertama.. Jakarta: Direktorat Pembinaan Sekolah Menengah Pertama Kementrian Pendidikan Nasional.

Lickona, T. (1991). Education for character: How our school can teach respect and responsibility. New York, Toronto, London, Sydney, Aucland: Bantam Books.
Majid, A., \& Andayani. (2013). Pendidikan karakter perspektif islam. Bandung: PT. Rosdakaya.

Rochayati, U., \& Wardani, R. (2018). Model pembelajaran karakter kerja di sekolah menengah kejuruan. Jurnal Kependidikan, 2(1), 116-127.

Rohmadi, M., \& Taufik, A. (2010). Pendidikan agama islam: Pendidikan karakter berbasis agama. Surakarta: Yumas Pustaka.

Schermelleh-Engel, K., Moosbrugger, H., \& Mueler, H. (2003). Evaluating the fit of structural equation models: Tests of significance and descriptive goodness-of-fit measures. Methods of Psychological Research, 8(2), 23-74.

Sjarkawi. (2015). Pembentukan kepriadian anak: Peran moral, inteletual emosional, dan sosial sebagai wujud integritas membangun jati diri. Jakarta: PT Bumi Aksara.

Solihati, N., Hikmat, A., Jupri, A. R., \& Hidayatullah, S. (2019). Nilai pendidikan karakter dalam permainan rakyat di lereng gunung merapi. Jurnal Kependidikan, 3(1), 28-42

Sopiatin, P., \& Sahrani, S. (2011). Psikologi belajar dalam perspektif islam. Bogor: Ghalia Indonesia.

Sujiono, \& Nurani, Y. (2012). Konsep dasar pendidikan anak usia dini. Jakarta: PT Indeks.

Supartinah, Kawuryan, S. P., \& Hastuti, W. S. (2018). Pedoman penjenjangan buku bacaan berbahasa Jawa bermuatan pendidikan karakter untuk sekolah dasar. Jurnal Kependidikan, 2(1), 26-38.

Wibowo. A. (2013). Pendidikan karakter anak usia dini. Yogyakarta: Pustaka Pelajar.

Wulandari, T., Wijayanti, A, T., \& Saliman. (2019). Pendidikan karakter dalam keluarga melalui pola asuh orang tua. Jurnal kependidikan, 3(1), 129-142. 